\title{
The Research on the Training Mode of Applied Technical Talents Based on BSP Ability Guidance
}

\author{
Zhang Shijun, Yu Guihua \\ City College, Wenzhou University, Wenzhou, China
}

Email address:

Zsj990901@163.com (Z. Shijun)

To cite this article:

Zhang Shijun, Yu Guihua. The Research on the Training Mode of Applied Technical Talents Based on BSP Ability Guidance. Education Journal. Vol. 4, No. 1, 2015, pp. 27-32. doi: 10.11648/j.edu.20150401.16

\begin{abstract}
The University of Applied Sciences is the future school-running orientation of newly established universities. It is an important significance for us to be clear about the training goal, training mode, and the implementation path of the University of Applied Sciences. We take the major of international economy and trade of newly built university as an example, analyzing the transition ways of training mode about applied technical talents, exploring the training mode and the operation mechanism based on BSP ability guidance, concluding the successful experience, and offering the examples and the references for related major construction in this paper. All those above have important practical significance.
\end{abstract}

Keywords: University of Applied Sciences, BSP Mode, Modularization Course System, Multilayer Practical Teaching System

\section{Introduction}

In the latest years, our country has devoted itself to transforming economic development ways, adjusting industrial structure, and attaching importance to the technology of original innovation and newly developing industries. That urgently requests that the reform of higher vocation education should be deepened and the contribution rate that vocation education gives economic transform should be promoted quickly. National higher education planning implements classification management to colleges and emphasizes training of application talents. The institution reform puts forward new request to development of higher vocation education. At the same time, higher vocation schools will prominently show their training feature of application talents, promote training quality of talents, strengthen combination ability of product and learning and social service ability, promote comprehensive strength and nucleus competitiveness and be offered with new development opportunity.

At present, the city college of Wenzhou university reached a consensus about problems such as how to achieve healthy and sustainable development, how to achieve stable development etc.. Thoughts were unified and new targets were established. School captured the opportunity that our country adjusted and reformed higher education to develop quickly. School insisted on mission of local university, found positioning of application university, and trained much more application technical talents that society needed. Therefore, teaching infrastructure of school was strengthened. Teaching reform was deepened continuously. Training feature formed. The feature was to train application technical talents that adapted to construction request of area economic society and coordinately developed their knowledge, ability, and quality. For the major of international economy and trade in City College of Wenzhou University, in order to adapt to the new positioning of talents training mode and locally economic development's needs for this kind of talents, it explored practically continuously. In order to understand the requirement conditions that enterprises needed from talents of this major, we listened to opinions and proposals of enterprise experts to scientifically set courses and teaching modes. We operated a deeply professional survey of large scale. The survey targets were brother schools of related major, related enterprises such as foreign trade companies, entry trade companies, goods-carry companies etc., and feedback and returning visit of graduates. The applied survey forms were giving out questionnaires, telephone visit, network consulting, and small communication meeting of survey. We understood problems of three aspects by professional survey: enterprise 
industries and profession post groups that major of international economy and trade in our school was facing, social request amount of talents that were trained in majors related to economy and trade in our school, industries' requirement and enterprises' requirement for talents, knowledge, ability, and quality on undergraduate level. According to professional survey, we reformed current talents training mode combining features of this major. We highlighted characteristic request of application talents training, which was quick action and enough aftereffect. We also explored reform scheme of innovation talents training mode based on profession ability guidance.

\section{The Analysis of Training Mode about BSP Talents}

In the years' teaching process, the major of international economy and trade in City College of Wenzhou University continuously makes innovation for talents training mode. On the previous basis of talents training mode of cooperation of school and enterprise, this research combines professional survey and puts forward exploratory talents training mode of BSP comprehensive profession ability according to the new requirement that modern industry development needs from talents.

Talents training mode of BSP comprehensive profession ability regards "serving industrial development needs in Wenzhou city, serving talents request of industry and enterprise" as starting point, regards deep cooperation of school and enterprise and binary main body training as the main form, regards course system of "platform plus module" as carrier, and regards multilayer practice teaching system as impetus. The mode will train application talents that own basic profession ability, special profession ability, and post profession ability (Figure 1).

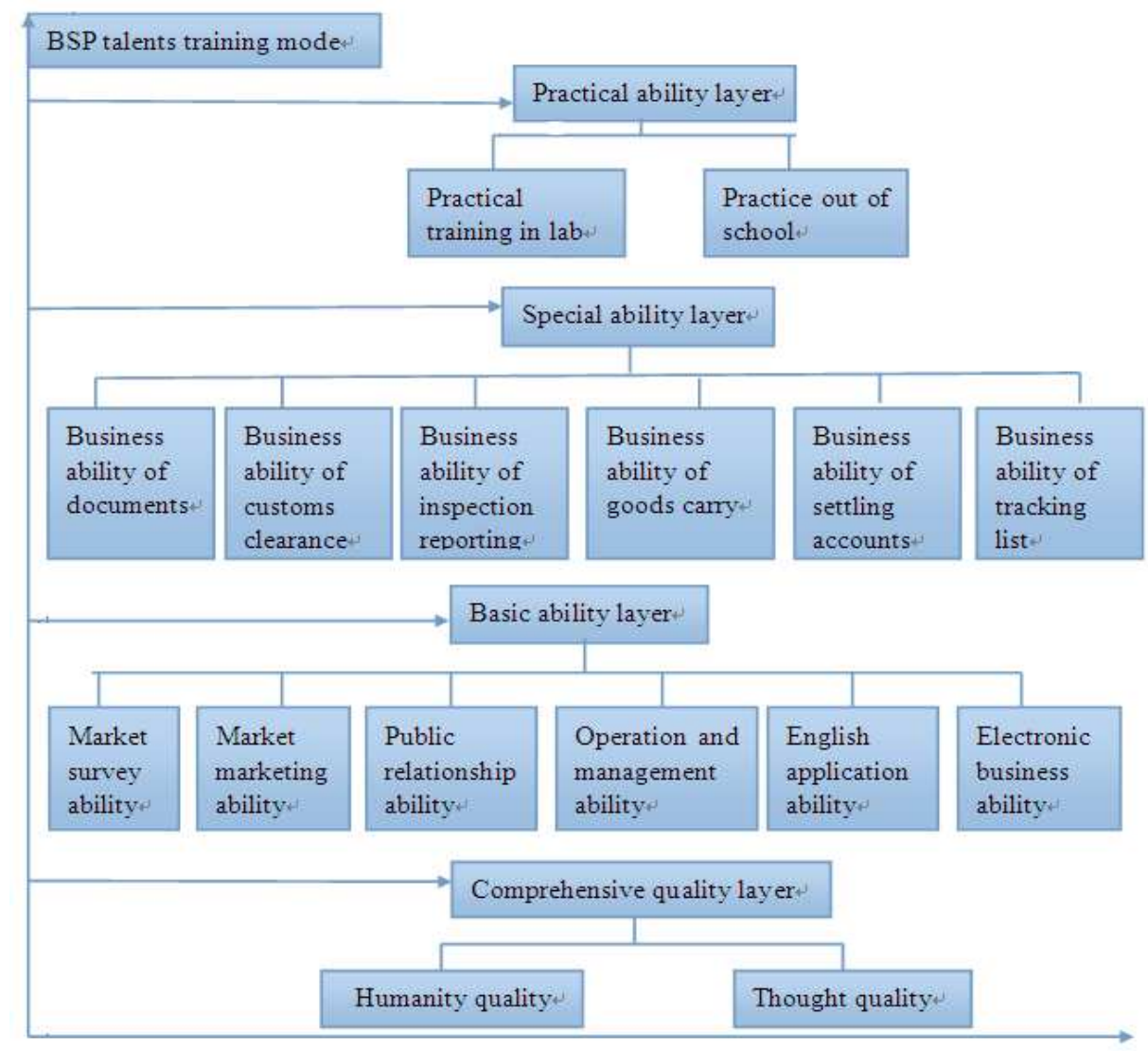

Figure 1. Professional Ability System Based on BSP Mode.

"B" represents Basic Professional Ability. It is basic knowledge system that students need for professional post later. It can include market survey ability, trade negotiation ability, market marketing ability, public relationship ability, operation and management ability, English application ability, and electronic business ability etc.

"S" represents Special Professional Ability. It is special skill that students need for professional post of international trade after graduation. It includes making ability of documents, business ability of customs clearance, business ability of inspection reporting, business ability of tracking list, business ability of settling accounts, and business ability of goods carry etc.

" $\mathrm{P}$ " represents Practical Professional Ability. It is practical professional ability of work-learning combination that faces product line of foreign trade enterprise and logistics enterprise. It includes practical training in school and practice ability out of school. 


\section{The Implementation Ways of BSP Talents Training Mode}

\subsection{The Repositioning of BSP Talents Training Mode}

We comprehensively implement integrated running idea of school for university of applied sciences. We take the reform of talents training mode as entry point, taking the modularization curriculum construction as a core, taking multilayer practical teaching system as means. We strengthen basic principle of combining necessary theoretical teaching with training of practical operation ability. We comprehensively propel construction of curriculum system and practical teaching system, walk on the road of professional construction and development combining production and learning, and training the advanced economy and trade application talents that are extravert and compound and accord with area economy construction and social development needs. Graduation students' professional direction in major of international economy and trade in city college of Wenzhou university is business post or related operation and management post from kinds of foreign economy and trade enterprise, three-capital enterprise, production enterprise that has operation right of import and export, business enterprise, and transportation, insurance, customs clearance, inspection reporting, list making, list tracking that are about import goods and export goods.

\subsection{The Knowledge Structure of BSP Talents Training Mode}

In knowledge structure, basic knowledge with certain humanities and social sciences, natural science and social science is needed; basic knowledge with computer operation and network application is needed; knowledge with certain aspects of listening, speaking, reading, and writing about professional English is needed; knowledge with certain management and interpersonal relationship is needed. In ability structure, good basic ability(interpersonal communication ability, social adaptability, ability of logic thought, ability of obtaining knowledge) is requested; basic skill of systematically mastering professional knowledge is requested; elementary innovation ability and ability of starting business is needed; powerful employability and professional operation ability is also needed. In quality structure, we should focus on training students' spirit of cherishing posts and devoting wholeheartedly to work, professional morality quality of working diligently, healthy mental quality, good quality of humanistic and social science.

\subsection{The Implementation Principle of BSP Talents Training Mode}

For the effective implementation of BSP talents training mode, "one principal line", "two emphasis", and "three breakthroughs" are needed to do.

"One principal line": It regards basically professional operation skill needed by posts of international economy and trade as main body, and highlights training of professional practical ability.

"Two emphasis": The first one is to highlight structural optimizing of three curriculum modules, which are professionally basic knowledge skill, professionally related knowledge skill, and professional knowledge skill, to build internal relation of three curriculum modules, and to highlight training of students' comprehensive ability. The second one is to highlight the tight combination of quality training, knowledge imparting and ability promotion, to highlight training of professional morality and innovation ability, to permeate contents of professional morality and attitude education into curriculum settings, to fuse the training of practical ability, comprehensive ability and innovation ability with teaching, and to make students be qualified advanced application talents of economy and trade kind.

"Three breakthroughs": The first one is to comprehensively break through previous traditional curriculum idea, which is "highlighting theory and despising practice". And it is to emphasize building new curriculum idea of strengthening basis and emphasizing practice. The second one is to greatly break through traditional education idea of "highlighting knowledge imparting and despising ability training", and to build modern education idea of sustainable development that emphasizes ability training. The third one is to effectively break through teaching idea in which theory knowledge curriculum and practice knowledge curriculum are disconnected, to build teaching idea of fusing theory with practice, and to achieve "you have me and I have you". Theory and practice promote and permeate mutually, and are trained at the same time.

\subsection{The Modularization Curriculum System of BSP Talents Training Mode}

We regard training of profession ability and profession quality about international trade post as principal line, regard knowledge, ability, and quality as main content, rebuild curriculum system, and build six platforms (professional education platform, innovation education platform, specialty education platform, specially basic platform, public basic platform, and quality education platform). In addition, we set different modules under platforms combining major feature, form curriculum system of "platform plus module", achieve the transformation of curriculum system from knowledge systematicness to knowledge application, and achieve the transformation from emphasizing knowledge inheriting to coordinately developing knowledge, ability and quality.

"Quality education platform": It is to train comprehensive quality of qualified citizens through integrity links such as morality education in curriculum and out of curriculum, etiquette education, campus culture edifying, kinds of activities of giving love etc. on the layer of school.

"Public basic platform": It is to make innovation for public basic platforms of math and English on the layer of school. It is to enhance learning interest of students and strengthen basis of math and English through careful selection, recombination, and enriching of curriculum contents. 
"Specialty basic platform": On the layer of secondary college, it is to build specially basic platform and get through teaching of specialty basic curriculums such as management, western economics, accounting etc. in the scope of college. For related curriculums, under the premise of offering sufficient and reasonable guarantee for class time, we maintain moderate standard and request in content intensity and knowledge coverage.

"Specialty education platform": On the layer of secondary college, it is to build specially education platform. For the nucleus curriculums in major of international economy and trade such as actual business of international trade, actual business of customs declaration and inspection reporting, actual business of foreign-trade documents, international account settling, business letter and telegraph of foreign trade, we put forward higher standard in aspects of teacher selection and distribution, textbook selection, teaching link setting etc.. We almost achieve double-teacher institution of giving lessons.

"Innovation education platform": On the layer of school, it is to train innovation consciousness and innovation ability of students and develop innovation thoughts of students through combining curriculum teaching activities and extracurricular innovation activities, combining on-campus activities and off-campus activities, and kinds of professional skill competition etc.

"Education platform of obtaining employment and starting business": It is to make students know major background, promote students' operation ability of post skill, narrow the distance between learning and working, and meet the request of employing units through on-campus practice and off-campus practice activities. It aims at highlighting "emphasizing application" under the premise of thickening basis.

\subsection{The Multilayer Practice Teaching System of BSP Talents Training Mode}

In order to match reform of BSP talents training mode, we build practice teaching system with multi-layer and multi-direction according to thought in which spatial structure and working site coincide. Multi-layer is to divide experimentally actual training into four layers (basic skill type, business skill promotion type, comprehensive ability promotion type and graduation design) according to connotation of experimentally actual training. Multi-direction is to regard "acknowledgement practice, social practice, simulation teaching in lab, graduation practice and thesis" as organic constituent part of practice teaching.

\subsubsection{Acknowledgement Practice}

Acknowledgement practice is practice teaching link in which students touch society, train communication ability, practice ability, and ability of solving problems. Acknowledgement practice of the major of international economy and trade includes macroscopical conception knowledge such as recognizing development prospect of foreign trade, current situation and existing problems of import and export, laws and rules of foreign trade, overall operation flow of foreign trade etc.. College organizes and leads students to visit foreign trade company, production enterprise, logistics enterprise, customs clearance and inspection unit, loading and discharging port etc.. In addition, our college invites industry experts that have practical experience of foreign trade to make reports. We motivate students' learning enthusiasm and enhance students' major acknowledgement on the base of major sensibility.

\subsubsection{Social Practice}

We motivate students to arrange themselves and to further deepen the comprehension about major of international economy and trade through adding summer social practice to practice teaching system, requesting students participate in some social practice activities in summer vacation and winter vacation, and endowing credits to that. We make students survey function units related to foreign trade such as foreign trade company, production enterprise of foreign trade type, customs, commodity inspection authority, insurance company, bank etc.. Students combine major knowledge of international trade with actual enterprise operation through writing survey reports. That will enhance students' attention to the industry and train students' ability of thinking and analyzing problems.

\subsubsection{The On-Campus Simulation of Experiments and Practical Training}

We will build branch centers of experimental teaching for major of international economy and trade, perfect six practical training rooms with integration of learning and training, and meet three function needs: the first one is class teaching; the second one is software simulation related with business operation; the third one is to achieve immediate teaching in working site for off-campus part-time teachers using network. Firstly, we will further perfect comprehensive business practice- training center of international trade. Students will keep a foothold on global vision and master the whole process of import-export transaction systematically and comprehensively through the demonstration and operation of the practical training center. Students will independently complete import-export commodity transaction through simulation and promote operation ability of professional post. Secondly, we will upgrade practical training room of foreign trade document. Foreign trade document reflects detailed information of links in foreign trade business. It is one of the most pivotal links in import-export business. The filling of document directly relates to success of import-export business. Practical training room of foreign trade document refers to teaching practice link of related majors of foreign trade, systematically concludes and arranges lots of document practice, and offers a standard document teaching platform and practice platform for students. Thirdly, we will upgrade practical training room of sand table simulation. "Yongyou" practical training of sand table involves several aspects such as integral strategy of enterprise, market analysis, product research and development, sale, finance management, team cooperation etc. Practical training of sand table can make students experience integrated operation process of enterprise 
in learning like games, train students' management ability, make students be familiar with operation links of common enterprise. Fourthly, we will build SIMIS international practical training lab of balancing accounts. SIMIS international lab of balancing accounts will fuse abundant interaction cases, characters, videos, and diagrams into teaching process, which reflects preciseness and flexibility of international accounts balancing. That makes students get training of ability through professional practice environment and tools in the whole process of curriculum study and further deepen cognition and comprehension of theory. Fifthly, we will build SIMFORWARDER international goods-carry practical training room. International goods-carry lab simulates real business environment of modern goods-transportation agent industry and elaborately designs logistics operation business of different difficulties. Students are familiar with related flows and key nodes of foreign trade logistics and goods-transportation agent through operating simulation goods-carry companies.

\subsubsection{The Intensive Practice in Off-Campus Practical Bases}

We open up off-campus practice base, signing off-campus cooperation agreement with foreign trade company, production enterprise of foreign trade, customs clearance enterprise, goods-transportation Agent Company etc., and carrying out deep-layer cooperation of aspects. Firstly, we organize professional practice of job rotation system in off-campus practice bases through school-enterprise cooperation and satisfy curriculum practice needs of talents training. Secondly, we open up short-term practice of foreign trade fair, continuously cooperate with sponsor and offer short-term practice opportunities for students making use of annual foreign trade fair. Thirdly, we select and dispatch professional teachers to take a temporary post in off-campus practice units to practice, promoting their practice operation ability, and train teachers of double-teacher quality.

\subsubsection{The Distributed Graduation Practice}

The distributed practice before graduation is that students go to practice units contacted by them to do post practice on the spot after they complete the stipulated curriculums in major teaching plan. The selection of practice units for major of international economy and trade can adopt flexible and diverse ways such as college contact, contact on students' own etc.. Through distributed graduation practice, students will be familiar with operation skill of import-export business links; mastering practical operation process of international accounts balancing, and training their practice ability and communication ability.

\subsubsection{Graduation Design Practice}

Graduation design is an important practice teaching link that undergraduate students finish at last in major of international economy and trade. Through designing graduation designing mission according with major, whole-process guidance of professional teachers, arranging documents and materials, and practical survey, students can use their major theory knowledge to analyze, study, and solve practical problems in international trade activities independently.

\section{The Supporting Guarantee Measures of Training Mode about BSP Talents}

\subsection{Building Double-Subject Cooperation System of Deep School-Enterprise Fusion}

We will change the previous mindset of training talents in single aspect of school, forming the cooperation system of several parties such as school; enterprise, industry, and making enterprise and industry to participate in training talents. Through the deep school-enterprise cooperation, we will absorb first-line workers in industry and enterprise participating in teaching activities, which include carrying out lecture, opening up courses, participating in teaching reform, revising scheme of talents training, formulating teaching outline etc. Even they can undertake the responsibility of talents training for a span of time. School carries out talents training work through the deep-layer cooperation with enterprise and industry, offering diversified major vision and teaching resource for students, and improving talents training specification and quality positioning.

\subsection{Building Diversified Curriculum Assessment Ways}

We will put forward the reform of assessment ways and build diversified assessment ways. The assessment contents not only include knowledge system, but highlight the assessment for students' professional practice ability. The assessment ways can include operation, design, making, case analysis, course conclusion, curriculum design, oral examination, explanation, operation demonstration, skill competition etc. the assessment places include classroom, lab (practical training room), off-campus practical base, off-campus practical training base. At the same time, we will absorb enterprise workers together to participate in and host part practical exams.

\subsection{Strengthening Practically Teaching Management}

We will formulate and improve the rules and regulations such as experiment, practice, practical training, and design etc., and focusing on supplementing the management institution of school-enterprise training talents. We will formulate and improve the quality standard of practical teaching links such as lab, on-campus and off- campus practice bases, graduation design, graduation practice etc., and building institution of quality appraisal. We will use some forms such as common appraisal of school and enterprise, employing enterprise to participate in appraisal etc. according to our needs. We will improve opening management ways of labs and practical training rooms, build network information platforms which have abundant teaching resource and are suitable for open teaching, and encourage students to participate in professionally practical training activities independently. 


\section{Conclusion}

The main responsibilities of practical local universities is cultivating practical talents and serving for the local industrials and enterprises, for the purpose of promoting economic and social development in this region. For this reason, production-teaching cooperative education is the key point to achieving the application talents of such kind of universities. New applied talents of the local colleges, the targeting of the talent of such institutions should cultivate practical and creative ability. Practical teaching system to build crucial for the development of the new Local Colleges.

New local colleges in personnel training objectives, the configuration of the teachers, practice teaching base as well as practice teaching management system, there are varying degrees of problems, the lack of a satisfactory practice teaching system to guide colleges and universities to carry out the practiceteaching, leading to difficult to achieve its objective of personnel training. Analysis and study of the problems in the new practice of local colleges teaching system can help solve these problems, and build a practical teaching system suitable for new local colleges, to promote the development of higher education in China.

Either in theory or in practice our new local universities in personnel training in the application are relatively backward; there are many problems in practice due to the lack of theoretical guidance. In order to describe them specifically, herein we specially selected X College as the study object of our research. Through the forms of the field research, interviews and questionnaires we try to get an in-depth understanding of the efforts which the X College made in the applied talents and the existing problems.

In order to develop a successful social needs of the application-oriented talents, the new local colleges need to work from the following aspects: on the terms of ideology, we must have a clear understanding of the applied talents, they have their own characteristics and connotations; on the development of personnel training programs, we should continue its optimization based on the practical problems of teaching practice; on practice teaching, we should focus on students' vocational skills needed in the future and the professional qualities needed for occupation.

\section{Acknowledgements}

Research Project of Zhejiang Education Scientific Planning (2015SCG177).

The Project Outcomes of Key Research Base about Social Sciences in Wenzhou City (14jd07).

General Project of The Department of Education in Zhejiang Province (Y201430449).

Department Project: Teaching Situation and Countermeasures on the Course of Ideological and Political in Private Colleges in Wenzhou.

\section{References}

[1] Jianguo Shen, Jianping Cai. The Analysis of the Coordination about the Major Structure of Higher Vocational Education and Area Feature Clustering Economy, Vocationally Technical Education, 2014(2):5-8.

[2] Jing Su, Pan Xiao, Qiang Zhu. The Discussion about the Construction of Local Applied Technical College and the Transformation of Local Ordinary University of Undergraduate Education, Henan Education, 2014(6):3-4.

[3] Qingguo Meng. The Analysis of the Reality and Features about the Running Applied Technical College. Vocationally Technical Education, 2014(10):5-10.

[4] RobertAnderson. British Universities: Past and Present, London :Hambledon Continuum, 2006: 77-78, 73.

[5] Alan Wm Wolff. China's Drive Toward Innovation. Issues in Science and Technology. Washington: Spring, 2007, 23(3).54-55.

[6] Graduate School of Education. Harverd University About HGSE. http:// www.gse.harvard.edu/ about/ index.html, 200922228. 